\title{
Upgrading of Three Subspecies of Eudigraphis takakuwai to the Species Rank (Diplopoda: Penicillata: Polyxenida: Polyxenidae)
}

\author{
Shigenori Karasawa ${ }^{1}$, Keisuke Kawano ${ }^{2}$, Shin-ichi Fukaya ${ }^{3}$, and \\ Nobuo Tsurusaki ${ }^{1,4}$ \\ ${ }^{1}$ Laboratories of Biodiversity and Animal Taxonomy, Faculty of Agriculture, Tottori University, Tottori 680-8551, Japan \\ E-mail: ntsuru@tottori-u.ac.jp \\ ${ }^{2}$ The Firefly Museum of Toyota Town, Nakamura 50-3, Toyota-cho, Shimonoseki, Yamaguchi 750-0441, Japan \\ ${ }^{3}$ Sugiyama-so 202, Shimo-Ochiai 4-18-8, Shinjuku Ward, Tokyo 161-0033, Japan \\ ${ }^{4}$ Corresponding author
}

(Received 4 February 2019; Accepted 19 December 2019)

\begin{abstract}
Three forms of Japanese Eudigraphis (Penicillata, Polyxenidae), which have long been treated as subspecies of Eudigraphis takakuwai (Miyosi, 1947), i.e., E. t. takakuwai (Miyosi, 1947), E. t. nigricans (Miyosi, 1947), and E. t. kinutensis (Haga, 1950), are raised here to three distinct species. Overlap of their distributional ranges over wide areas of Japan was confirmed, and molecular phylogeny using both nuclear (ITS2) and mitochondrial (COI) DNA testified monophyly of each of the three forms. Additionally, the three forms can be easily distinguished from one another by body size, coloration, and habitat, though species identification for the specimens preserved in ethanol is often difficult due to their morphological similarity other than coloration and size. Description of some so-far neglected morphological characters were provided with some SEM photos to supplement knowledge on taxonomy and morphology of the family.
\end{abstract}

Key Words: Eudigraphis, Penicillata, taxonomic status, molecular phylogeny, revision.

\section{Introduction}

Eudigraphis takakuwai (Miyosi, 1947) (Penicillata: Polyxenida: Polyxenidae) is a tiny species (less than $5 \mathrm{~mm}$ in body length) of Japanese millipede that resembles the larvae of dermestid beetles. The species usually inhabits soil litter on the forest floor, space under tree trunk bark or cracks of rocks in seashores, or the arboreal nests of ants (Shinohara and Tanabe 1999; Shinohara et al. 2015). This species has long been treated as a polytypic species comprised by three subspecies: E. t. takakuwai (Miyosi, 1947), E. t. nigricans (Miyosi, 1947), and E. t. kinutensis (Haga, 1950) (Shinohara and Tanabe 1999; Nguyen Duy-Jacquemin and Geoffroy 2003; Shinohara et al. 2015; Sierwald and Spelda 2019). Of the three subspecies, E. t. takakuwai was widely known from southwestern Japan, while known records of the other subspecies E. t. nigricans and E. t. kinutensis were mostly restricted to the Kanto District, central part of Honshu.

Although these three forms were originally described as subspecies of the singular "Monographis takakuwai" (Miyosi 1947; Takashima and Haga 1950), the difference in their habitat preference has also been noticed since their original descriptions. The "takakuwai s. str., "nigricans", and "kinutensis" are usually found from "soil litter and under barks of tree trunks in the forest", "cracks of rocks in seashores", and "under barks of tree trunks in urban or suburban parks", respectively. Probably due to the distinct differences in their habitats, body size, and coloration, these forms have also been occasionally treated as full species (Haga 1951; Ishii and Tamura 1995; Ishii 1997, 1999, 2002). However, the authors of those articles have neither manifested any taxonomical changes nor presented reasons for the taxonomical treatment. Moreover, the authors have never been consistent for the treatment (cf. Ishii 2005, 2018; used the name E. t. kinutensis). Thus, in most of the articles in which Japanese Eudigraphis appeared, including several influential books and articles (Shinohara and Tanabe 1999; Nguyen Duy-Jacquemin and Geoffroy 2003; Shinohara et al. 2015; Minagoshi 2017; Sierwald and Spelda 2019), these three forms have been treated as subspecies of E. takakuwai. It seems that insurmountable psychological barriers in accepting that these are not subspecies of a single species but distinct species is due to the difficulty in separating them clearly. The ethanol-immersed specimens were decolored and lost many detachable bristles, which are easily separated from the body to entangle enemies (Eisner et al. 1996). Their patterns of distribution are generally allopatric ("takakuwai s. str." in western Japan, "nigricans" in the coastal areas of southwestern part of Kanto District, and "kinutensis" in Tokyo and its vicinities) except for rather limited areas in and around Tokyo where the three forms are alternately found. Sperm transfer during the mating of Penicillata, including Eudigraphis, is indirect and males of the group do not have specialized appendages for sperm transfer. Because male gonopod morphology is often species specific and hence useful in species identification in all the other millipedes (Hopkin and Read 1992), it is likely that 


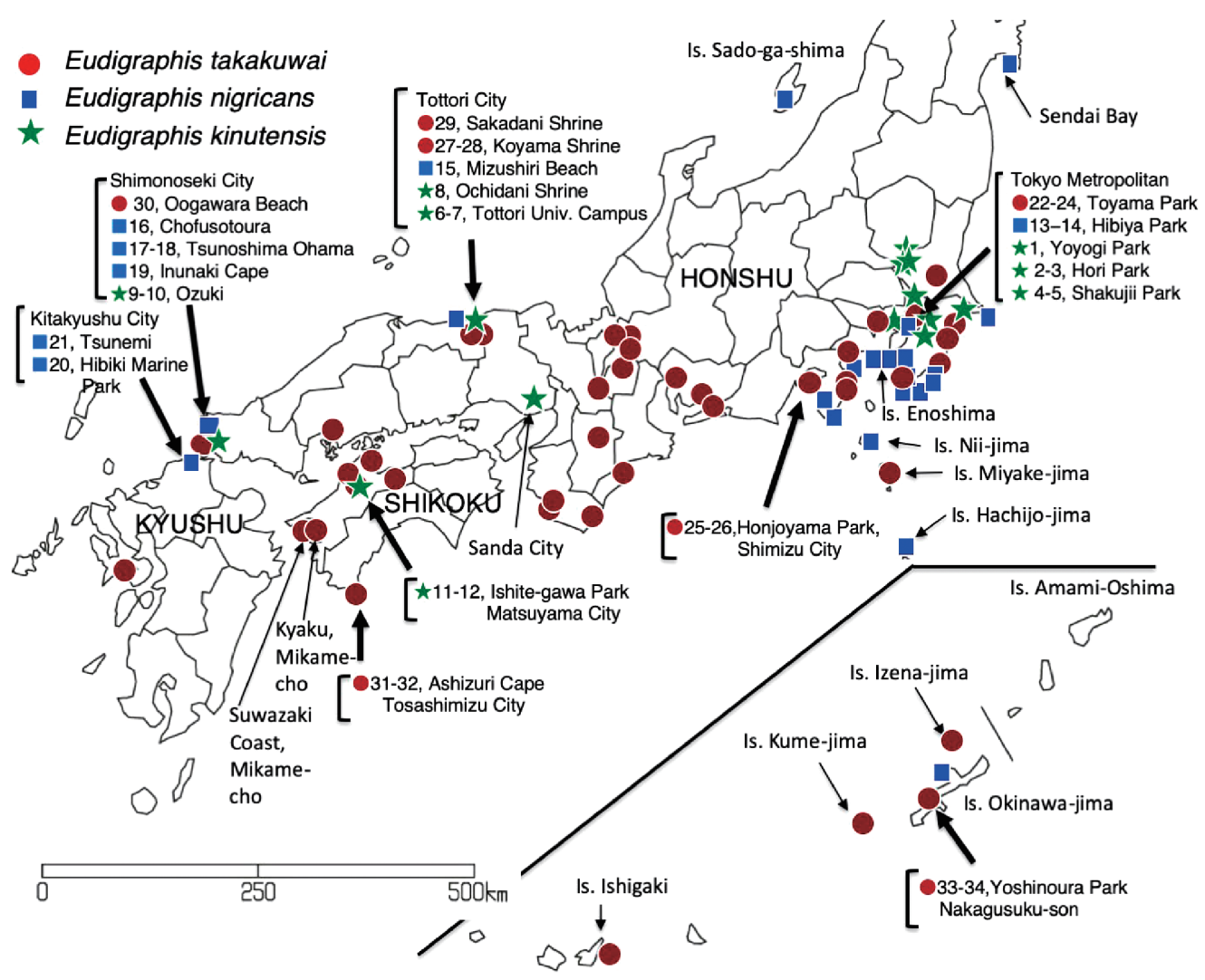

Fig. 1. Distribution of three species of Eudigraphis with source of samples used for molecular phylogenetic analysis. Localities of samples are shown in brackets. Sample numbers correspond to those in Table 1 and Figs 2, 3. Literature and new records were also incorporated.

the lack of male gonopods in this group has also hampered resolution of the species/subspecies issue.

Recently, we found some populations of "nigricans" and "kinutensis" in the western part of Japan covering wide areas ("nigricans" from the western part of Honshu and Kyushu and "kinutensis" from western part of Honshu and Shikoku). Thus, treatment of the three forms as three subspecies is no longer supported, because "subspecies" represent geographical races in a single species in animal taxonomy (Mayr and Ashlock 1991; Winston 1999). We performed phylogenetic analyses for these populations of Japanese Eudigraphis using both the internal transcribed spacer 2 (ITS2, ca. 600 bp) of nuclear DNA and cytochrome $c$ oxidase subunit I (COI, $c a$. $600 \mathrm{bp}$ ) of mitochondrial DNA to resolve the phylogenetic relationships of these populations and to set the taxonomical treatment straight. In this paper, we will report results of the phylogenetic analysis and provide a revision of taxonomy of the species of Japanese Eudigraphis with information on biology so far accumulated for the group.

\section{Materials and Methods}

Taxon sampling. A total of 34 specimens from 21 localities (13 specimens of 7 populations of "takakuwai s. str., 9 specimens of 7 populations of "nigricans", and 12 specimens of 7 populations of "kinutensis") were sampled for phylogenetic analysis of DNA (Fig. 1; Table 1). All the specimens were fixed and preserved in $99 \%$ ethanol, though some samples were first fixed and preserved in $80 \%$ ethanol, then transferred to $99 \%$ ethanol. All the specimens used for morphological observation (except for some used for SEM observation and some severely damaged through dissection) will be deposited in the Zoological Collection of Kyoto University (KUZ).

Morphological observation. Morphological observation was made for slides mounted with glycerol and Hoyer's medium. For scanning electronic microscopy images, specimens were dehydrated in solutions of increasing concentration of ethanol ( $80 \%$ to $100 \%$ ) and finally $100 \%$ t-butanol and freeze-dried by using a freeze dehydration equipment JEOL JFD-310 and examined using a Keyence VHX-D510 without any metal-coating.

DNA extraction and PCR amplification. Total DNA was extracted from the posterior half of body or head using the Qiagen DNeasy Blood and Tissue Kit (Qiagen, Germany), according to the manufacturer's protocol. Body parts remained were preserved as voucher specimens in KUZ. A partial region of the mitochondrial cytochrome $c$ oxidase subunit I (COI) and the internal transcribed spacer 2 (ITS2) region of nuclear ribosomal DNA were amplified by polymerase chain reaction (PCR) using the following primers: COS2183 and COA2745Y for the COI region (Tanabe and Sota 2008), LSU1 and LSU3 for the ITS2 region (Wade and Mordan 2000). PCRs were carried out in $7.5 \mu \mathrm{l}$ Multiplex PCR Master Mix (Qiagen, Germany), $0.75 \mu \mathrm{l}$ of each primer pair, $1.5 \mu \mathrm{l}$ distilled water, and $4.5 \mu \mathrm{l}$ sample DNA. The cycle program comprised initial denaturation $95^{\circ} \mathrm{C}$ for $15 \mathrm{~min}$, 
Table 1. Identification (ID), sampling sites, and the INSDC accession numbers of specimens used for the phylogenetic analyses. Acronym: KUZ, the Zoological Collection of Kyoto University.

\begin{tabular}{|c|c|c|c|c|c|}
\hline \multirow{2}{*}{ Species } & \multirow{2}{*}{ ID } & \multirow{2}{*}{ Voucher } & \multirow{2}{*}{ Sampling sites } & \multicolumn{2}{|c|}{ Accession No. } \\
\hline & & & & COI & ITS2 \\
\hline \multicolumn{6}{|c|}{ Eudigraphis kinutensis } \\
\hline & 1 & KUZ Z2628 & Yoyogi Park, Shinjuku Ward, Tokyo & LC456735 & LC456758 \\
\hline & 2 & KUZ Z2629 & Hori Park, Suginami Ward, Tokyo & LC456752 & LC456763 \\
\hline & 3 & KUZ Z2630 & Hori Park, Suginami Ward, Tokyo & LC456728 & LC456755 \\
\hline & 4 & KUZ Z2631 & Shakujii Park, Nerima Ward, Tokyo & LC456736 & - \\
\hline & 5 & KUZ Z2632 & Shakujii Park, Nerima Ward, Tokyo & LC456753 & LC456764 \\
\hline & 6 & KUZ Z2633 & Tottori University, Tottori City, Tottori & LC456730 & LC456757 \\
\hline & 7 & KUZ Z2634 & Tottori University, Tottori City, Tottori & LC456737 & LC456759 \\
\hline & 8 & KUZ Z2635 & Ochidani Park, Tottori City, Tottori & LC456729 & LC456756 \\
\hline & 9 & KUZ Z2636 & Ozuki Elementary School, Shimonoseki City, Yamaguchi & LC456744 & LC456760 \\
\hline & 10 & KUZ Z2637 & Ozuki Elementary School, Shimonoseki City, Yamaguchi & LC456754 & LC456765 \\
\hline & 11 & KUZ Z2638 & Ishite-gawa Park, Matsuyama City, Ehime & LC456745 & LC456761 \\
\hline & 12 & KUZ Z2639 & Ishite-gawa Park, Matsuyama City, Ehime & LC456746 & LC456762 \\
\hline \multicolumn{6}{|c|}{ Eudigraphis nigricans } \\
\hline & 13 & KUZ Z2640 & Hibiya Park, Chiyoda Ward, Tokyo & LC456732 & LC456771 \\
\hline & 14 & KUZ Z2641 & Hibiya Park, Chiyoda Ward, Tokyo & LC456725 & LC456766 \\
\hline & 15 & KUZ Z2642 & Mizushiri Beach, Tottori City, Tottori & - & LC456767 \\
\hline & 16 & KUZ Z2643 & Chohusotoura-cho, Shimonoseki City, Yamaguchi & LC456726 & LC456768 \\
\hline & 17 & KUZ Z2644 & Tsunoshima-ohama beach, Shimonoseki City, Yamaguchi & LC456750 & LC456772 \\
\hline & 18 & KUZ Z2645 & Tsunoshima-ohama beach, Shimonoseki City, Yamaguchi & LC456751 & LC456773 \\
\hline & 19 & KUZ Z2646 & Inunaki Cape, Shimonoseki City, Yamaguchi & - & LC456769 \\
\hline & 20 & KUZ Z2647 & Hibiki Marine Park, Kitakyushu City, Fukuoka & LC456747 & - \\
\hline & 21 & KUZ Z2648 & Tsunemi, Kitakyushu City, Fukuoka & LC456731 & LC456770 \\
\hline \multicolumn{6}{|c|}{ Eudigraphis takakuwai } \\
\hline & 22 & KUZ Z2649 & Toyama Park, Shinjuku Ward, Tokyo & LC456733 & LC456776 \\
\hline & 23 & KUZ Z2650 & Toyama Park, Shinjuku Ward, Tokyo & LC456734 & LC456777 \\
\hline & 24 & KUZ Z2651 & Toyama Park, Shinjuku Ward, Tokyo & - & LC456774 \\
\hline & 25 & KUZ Z2652 & Honjoyama Park, Shimizu Town, Shizuoka & LC456738 & LC456779 \\
\hline & 26 & KUZ Z2653 & Honjoyama Park, Shimizu Town, Shizuoka & LC456739 & LC456780 \\
\hline & 27 & KUZ Z2654 & Koyama Shrine, Tottori City, Tottori & LC456742 & LC456783 \\
\hline & 28 & KUZ Z2655 & Koyama Shrine, Tottori City, Tottori & LC456743 & LC456784 \\
\hline & 29 & KUZ Z2656 & Sakadani Shrine, Tottori City, Tottori & - & LC456778 \\
\hline & 30 & KUZ Z2657 & Oogawara Beach, Shimonoseki City, Yamaguchi & LC456727 & LC456775 \\
\hline & 31 & KUZ Z2658 & Ashizuri Cape, Tosashimizu City, Kochi & LC456740 & LC456781 \\
\hline & 32 & KUZ Z2659 & Ashizuri Cape, Tosashimizu City, Kochi & LC456741 & LC456782 \\
\hline & 33 & KUZ Z2660 & Yoshinoura Park, Nakagusuku Village, Okinawa & LC456748 & LC456785 \\
\hline & 34 & KUZ Z2661 & Yoshinoura Park, Nakagusuku Village, Okinawa & LC456749 & - \\
\hline
\end{tabular}

35 cycles of $94^{\circ} \mathrm{C}$ for $30 \mathrm{sec}$, annealing at $48-54^{\circ} \mathrm{C}$ for 90 sec, elongation $72^{\circ} \mathrm{C}$ for $60 \mathrm{sec}$, and final extension at $60^{\circ} \mathrm{C}$ for $30 \mathrm{~min}$. PCR products were purified using an illustra ExoProStar (GE Healthcare Japan Corp., Japan) and directly sequenced by Macrogen Japan (Japan) using the same primer sets used for PCR. The sequences have been deposited in the International Nucleotide Sequence Database Collaboration (INSDC) through DNA Data Bank of Japan (Table 1).

Phylogenetic analysis. The sequences were aligned using MAFFT version 7 (Katoh and Standley 2013). Although there was no gap in the COI sequences, the ITS2 sequences included gaps and were trimmed by the automated trimming heuristic method of trimAI (Capella-Gutierrez et al. 2009). Unrooted phylogenetic trees were constructed by maximum likelihood (ML) and Bayesian inference (BI) methods. ML analysis was performed using RAxML ver- sion 8 (Stamatakis 2014). The best-fit mixed model of codons for COI sequences was a partitioned equal mean rate by the Bayesian information criterion (BIC) in the program of KAKUSAN4 (Tanabe 2011), and the general timereversible plus gamma distribution $(\mathrm{GTR}+\mathrm{G})$ was selected for sequence evolution models of COI and ITS2. Bootstrap proportions (BP) for the ML analysis were assessed by 1000 replicates. BI and Bayesian posterior probabilities (BPP) were performed with MrBayes5D (available at https://www. fifthdimension.jp/products/mrbayes5d/). For COI sequence, the best-fit models of sequence evolution were HKY85+I for the first codon position, F81 for the second codon position, GTR for the third codon position, and the proportional model of these codons was selected by the BIC in the program KAKUSAN4. In contrast, the HKY85+G was selected for ITS 2 sequences. Based on the selected models, BI analy- 
sis was performed, which consisted of running four simultaneous chains for 1,000,000 generations with tree sampling every 1,000 generations. A 50\%-majority-rule consensus tree was generated, discarding the first 100,000 generations as burn-in. The program Tracer 1.6 (Rambaut et al. 2014) was used to determine when the log likelihood of sampled trees reached stationary distribution. Genetic distances of COI sequences among the three forms were calculated as $\mathrm{p}$ distances using MEGA7 (Kumar et al. 2016).

\section{Results}

We obtained 534 base pairs of COI sequence data for 30 specimens. In contrast, there were variations in length of

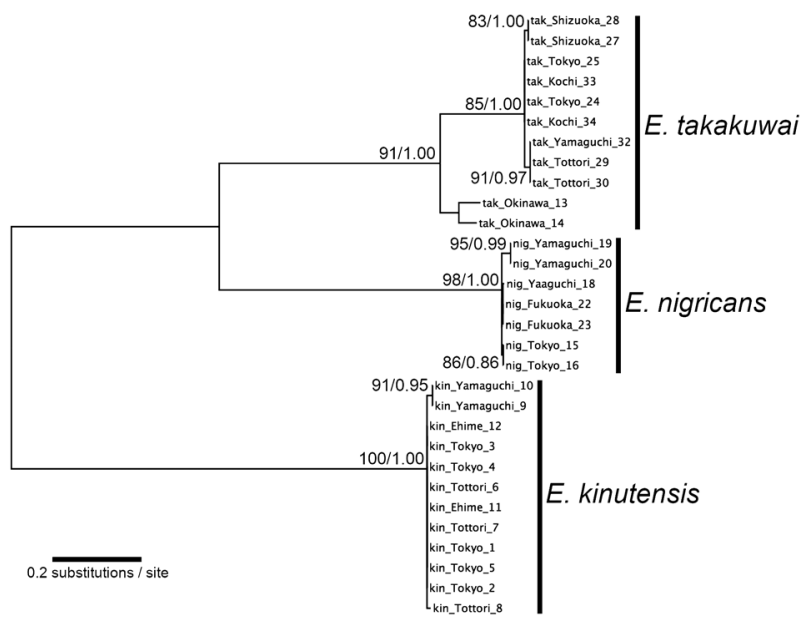

Fig. 2. Unrooted ML phylogenetic tree based on COI sequence data. Bootstrap proportions $(\mathrm{BP} \geq 85)$ of $\mathrm{ML}$ and Bayesian posterior probability $(\mathrm{BPP} \geq 0.95)$ are shown at each node $(\mathrm{BP} / \mathrm{BPP})$. The names of OTUs show species_locality_sample ID (details on Table $1)$.
ITS2 sequences (31 specimens): 652 bp for "nigricans", 640 or 641 bp for "takakuwai s. str.", and 630 or 643 bp for "kinutensis".

Four phylogenetic trees (ML and BI trees for COI and ITS2 regions) were constructed, and the topologies of $\mathrm{ML}$ trees were identical to those of the BI trees in both of the COI and ITS2 analyses. In both the phylograms of COI and ITS2 regions (Figs 2, 3), each of the three forms was well supported as monophyletic $(\mathrm{BP} \geq 91 \%, \mathrm{BPP}=1.00)$. The trees also showed that there was little genetic variation in each form, excluding specimens of "takakuwai" type from Okinawa-jima island. On the other hand, the phylogenetic analyses could not clarify relationship among the three forms, because of lacking information of outgroup. Genetic distances of the COI sequences among the three forms were more than 14.0\%: "nigricans" vs. "kinutensis", 15.4\%; "nigricans" vs. "takakuwai s. str.", 14.3\%; and "kinutensis" vs. "takakuwai s. str.", 14.1\%.

\section{Discussion}

As shown in Figs 2 and 3, all the specimens of Japanese Eudigraphis examined were grouped into three clades in both the phylograms based on mitochondrial COI (Fig. 2) and nuclear ITS2 regions (Fig. 3). Each of the three forms identified by a combination of body size, coloration, and habitat appeared as a monophyletic clade with almost no within-clade differentiation seen between phylogenetic reconstructions. We might expect there to be few or no geographic variations in the maritime "nigricans" and "kinutensis" that prefers trunks of trees in suburban parks (Takashima and Haga 1950; Ishii 1997), because of possible passive dispersal by marine current and possible long dispersal by the transplantation of garden trees, respectively. However,

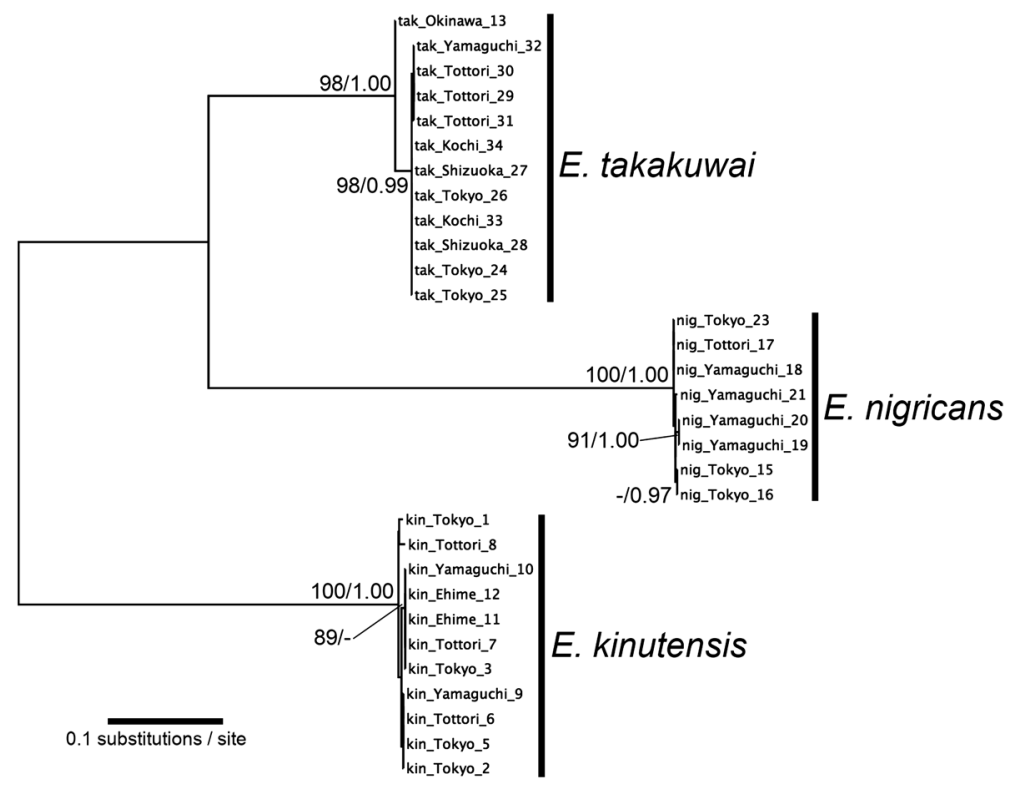

Fig. 3. Unrooted ML phylogenetic tree based on ITS2 sequence data. Bootstrap proportions ( $\mathrm{BP} \geq 85)$ of $\mathrm{ML}$ and Bayesian posterior probability (BPP $\geq 0.95)$ are shown at each node (BP/BPP). The names of OTUs show species_locality_sample ID (details on Table 1). 
interestingly, except for a population from Okinawa-jima island of the Ryukyu Islands, there was no differentiation also in the clade comprised of "takakuwai s. str." which might be less vagrant than other two forms because of their tendency to select soil litter on the forest floor as habitat (Takashima and Haga 1950). We also found that genetic distances among the three forms (14.1-15.4\%) are equal or larger than those reported for distinct species of millipede species (6.7-16.1\%; Wesener and Conrad 2016; Huynh and Veenstra 2018b).

As already stated, these three forms have long been treated as three subspecies of a single species E. takakuwai. However, the present phylogenetic reconstructions, where three distinct monophyletic clades appeared, and the fact that distributional ranges of the three forms widely overlap one another clearly support the idea that the three forms are distinct species isolated by some reproductive mechanisms.

Difference in the habitat preference among the three "species" is rather clear. Particularly, E. nigricans usually shows strong association with maritime habitat. However, one of us (SF) found a population of E. nigricans under barks of a tree trunk in the Hibiya Park in downtown Tokyo, ca. $1.8 \mathrm{~km}$ away from the nearest shore of the Tokyo Bay. Populations of E. takakuwai s. str. have been also found under the bark of tree trunks in suburban parks, though this form is usually associated with denser forests and the species can be most abundantly collected from soil litter with the help of a sifter or a Tullgren funnel. Interestingly, we have so far found no mixed-populations comprised by more than one species of Eudigraphis at a single site let alone on the same tree trunk. For example, in the urban parks of Tokyo where Eudigraphis millipedes have been found by one of us (SF), each population consisted of only a single species as exemplified in Fig. 1. It might be possible that there is some reproductive interference (Gröning and Hochkirich 2008) among them that make them impossible to co-occur.

\section{Systematics}

Genus Eudigraphis Silvestri, 1948

Eudigraphis Silvestri, 1948: 217 [type species: Eudigraphis japonica Silvestri, 1948 (=Eudigraphis takakuwai)]; Nguyen Duy-Jacquemin and Geoffroy 2003: 299; Short and Vahtera 2017: 2456.

Diagnosis. Head with 8 ocelli each side. Body with 10 segments, 9 pleural projections, a telson, and 13 pairs of legs in adults. Differs from Monographis Attems, 1907, in 6th antennal segments having just 3 bacilliform sensilla, respectively, and by having caudal trichomes with more numerous (range: 2-6) barbed hooks arranged in a line. Differs from Unixenus in the presence of a single usually continuous row of trichomes along the posterior edge of the tergites.

Included species. Six species: E. takakuwai, E. nigricans, E. kinutensis, E. sinensis Ishii and Liang, 1990, E. taiwanensis Ishii, 1990, and E. xishuangbanna Ishii and Yin, 2000.

Distribution. Japan, Taiwan, and China.
Remarks. Miyosi (1959) synonymized Eudigraphis with Monographis by expanding definition of the latter. However, Eudigraphis has been treated as a distinct genus different from Monographis since the revision of Monographis by Nguyen Duy-Jacquemin and Condé (1967) (also see Shinohara and Ishii 1984; Ishii 1988).

Japanese species of Eudigraphis seem to show close morphological similarity to Unixenus Jones, 1944 (Short and Huynh 2013; Huynh and Veenstra 2018a), especially in position and the number of bacilliform sensilla on distal segments of the antennae (cf., fig. 6 in Huynh and Veenestra 2018a) and in morphology of the gnathochilarium (cf., fig. $4 \mathrm{~F}$ in Huynh and Veenestra 2018a). However, Japanese Eudigraphis differs from Unixenus in morphology of biarticuated setae on the second legs and show similarity to Monographis in this character (cf., fig. 12 in Huynh and Veenestra 2018a). Separation of Eudigraphis from Unixenus seems to be supported by a molecular phylogeny provided by Short and Vahtera (2017). However, further detailed analyses seem to be needed.

\section{Keys to Japanese species of Eudigraphis}

1 Head black, body dorsally cream yellow with two rows of blackish brown stripes; body 3.0-4.2 mm long; usually inhabits sea cliffs ................. nigricans — Head pale brown or gray, body dorsally uniformly gray or cream yellow only laterally tinted with brown. .......2

2 Body cream yellow; body 3.8-4.5 mm long; usually inhabits forest floor or under bark of tree trunks in forest ..... ........................... takakuwai

— Body gray when alive; body $2.5-3.0 \mathrm{~mm}$ long; usually inhabits under barks of tree trunks in suburban parks .....

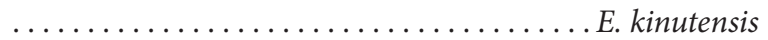

Remarks for "specimens examined". Data are given by the following order: Locality (DEG latitude-longitude data if available), altitude of the locality when available, vegetation or tree species on which specimens were collected, number of specimens (spm, spms), date collected, collector ( $\mathrm{SF}=$ Shin-ichi Fukaya, KK=Keisuke Kawano, NT=Nobuo Tsurusaki, $\mathrm{SK}=$ Shigenori Karasawa, $\mathrm{TM}=$ Takashi Mekata).

Eudigraphis takakuwai (Miyosi, 1947)

[Japanese name: Usuaka-fusayasude]

(Figs 1, 4B, 5A, B, 6A-C)

Monographis kraepelini (not of Attens, 1907): Takakuwa and Takashima 1942: 123, an unnumbered figure on p. 123; Takakuwa 1954: 18, fig. 18; Omine 1965: table 1.

Monographis takakuwai Miyosi, 1947: 2, figs 1, 2 [in part; type locality: Kyaku, Mikame-cho (Now a part of Seiyo City), Nishi-uwa-gun, Ehime Prefecture, Shikoku, Japan; type specimens seem to be lost].

Monographis takakuwai takakuwai Miyosi, 1947: 2, figs 1, 2; Takashima and Haga 1950: 22, fig. 1; Miyosi,1959: 58, pl. 1, fig. 1; Miyosi 1965: 741, one text-figure; Ishii 1977: 35; Miyosi 1979: 478, one text-figure; Ishii and Yamaoka 
1982: 767; Ishii and Yamaoka 1983: 41; Ishii 1983: 45.

Eudigraphis japonica Silvestri, 1948: 219 (type locality: Nagoya).

Eudigraphis takakuwai takakuwai: Murakami 1972: 85, fig. 4A; Ishii 1988: 957, figs 8, 9; Matsumoto and Gamo 1992: 54, figs 2-7; Murakami 1993: 97; Kuwahara 1993: 15;
Ogata 1997: 2, fig. 1 (photo); Nguyen Duy-Jacquemin and Geoffroy 2003: 99; Ichisawa et al. 2012: 13; Kawano 2017: 16 , figs $1,2$.

Eudigraphis takakuwai: Haga 1952: 15 (in part); Nguyen Duy-Jacquemin and Condé 1967: 80 (in part); Minato 1968: 20 (in part); Minato 1971: 46 (in part); Tanabe


Fig. 4. Typical habitats (A, C, E, arrowed) of Japanese Eudigraphis (B, D, F). A, B: E. takakuwai: A, Toyama Park, Shinjuku Ward, trunk of Zelkova serrata (17 October 2017); B, various stages were found under bark of trunks of Z. serrata at the same site. C, D: E. nigricans; C, Mizushiri Beach, Tottori City (18 October 2017); D, an adult found in the cavity under a rock. E, F: E. kinutensis; E, campus of Tottori University, Tottori City, Z. serrata (13 November 2017); F, E. kinutensis under the bark of trunks of Z. serrata (Ochidani Park, Tottori City, 10 November 2017). 
1992: 65; Ishii and Tamura 1995: 233; Ishii 1997: 257; Shinohara and Tanabe 1999: fig. 1 on p. 667; Tsurusaki 1999: 61; Ishii 1999: 212; Ishii 2000: 107; Takano 2001: 222; Ishii 2002: 298; Tsurusaki 2002: 151; Tsurusaki 2012: 285; Shinohara et al. 2015: fig. 1 on p. 964; Minagoshi 2017: 51, 2 photos.

Diagnosis. Body 3.8-4.5 mm long excluding caudal bundle with no difference between sexes. Ground color of body pale yellowish brown, including head, in dorsal view. Each segment of body laterally tinted with dark brown, though the markings easily fade away in preserved specimens in ethanol. Mandible with 7 molar processes and 9 molar combs (for the details in mandible structure, see Ishii 1988).

Brief description [based on specimens from Suwazaki Coast, a locality closely located to the type locality (Kyaku) of the species in Mikame-cho, Seiyo City, Ehime
Prefecture]. Body length without caudal bundle (males) $3.8-4.0 \mathrm{~mm}(n=2$, mean $3.9 \mathrm{~mm})$.

Coloration. Head and tergites lighter yellowish brown laterally tinted with brown.

Body with 10 segments, 9 pleural projections and a telson, 13 pairs of legs (Fig. 5A, B).

Head with 8 ocelli each side. Head with anterior rows of ca. 30 trichomes arranged in 2 closely positioned rows (Fig. 6C) and a middle rows of $c a .10$ trichomes and a posterior row with a few scattered trichomes (Fig. 6C).

The antennae with 8 articles as shown in Fig. 6A, B). Article VI with 3 thick basiconic sensilla $(\mathrm{T})$ ventrodistally of equal length; article VII ventrodistally with 2 thick basiconic sensilla (Fig. 6B). The presence of conical and setiform sensilla were unable to be determined.

Clypeo-labrum with 10 setae along posterior margin; anterior margin of labrum smooth, only slightly sinuated (Fig.

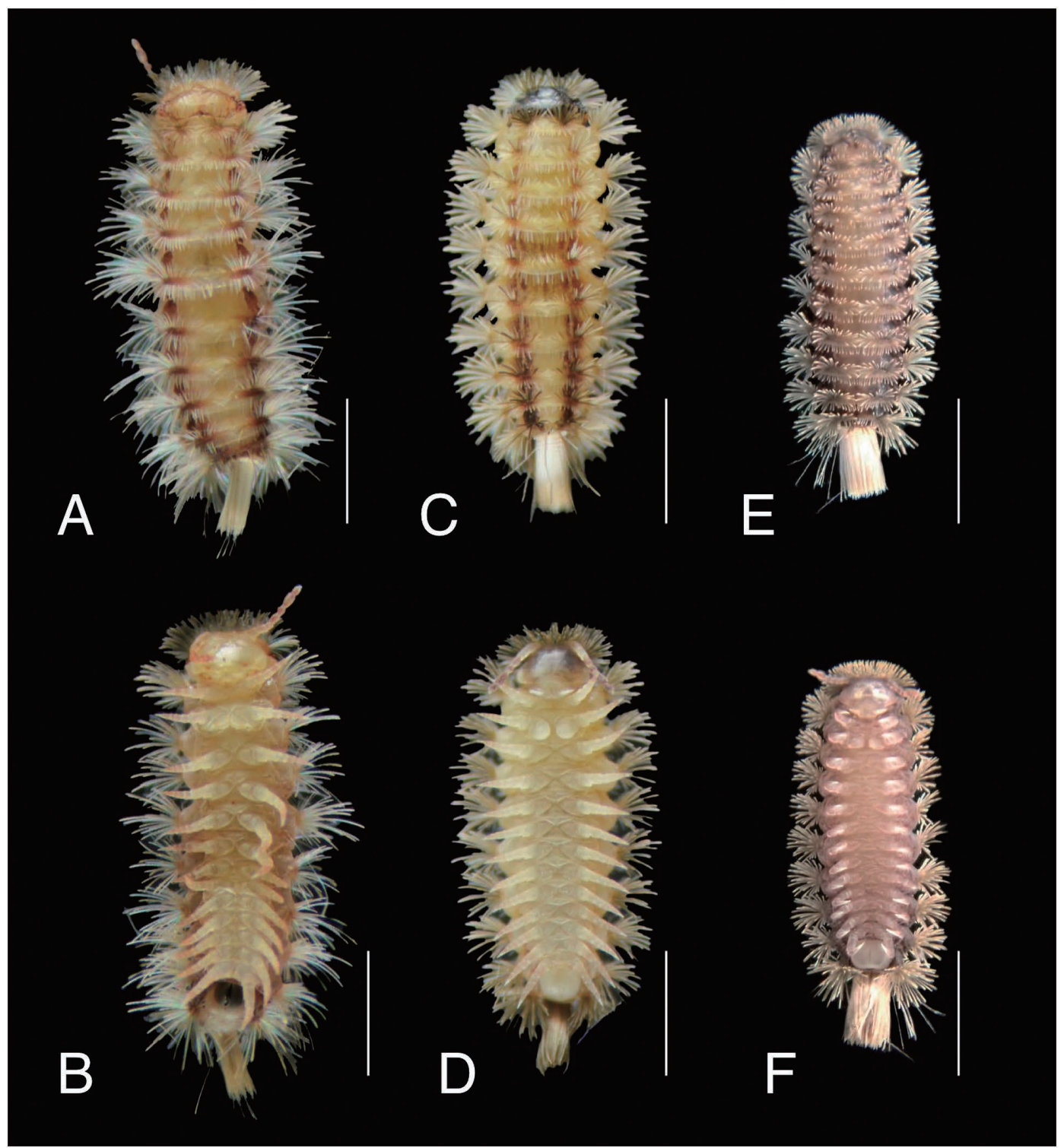

Fig. 5. Dorsal (A, C, E) and ventral (B, D, F) views of Eudigraphis. A, B: E. takakuwai, female (Waita, Toyoura-cho, Shimonoseki City, 31 August 2017). C, D: E. nigricans, male (Uka, Toyoura-cho, Shimonoseki City, 1 September 2017). E, F: E. kinutensis (campus of Tottori University, Tottori City, 5 January 2018). All the scales $=1 \mathrm{~mm}$. 
6A). Gnathochilarium with slender lateral palp with $12 \mathrm{cy}-$ lindrical sensilla, medial palp with $c a$. 10 sensilla.

Leg 1 without trochanter and tarsus 1 . Femur distoventrally with a biarticulated seta with a tall cylindrical funicle
(Fig. 6A). Leg 2 femur with similar biarticulated seta. Postfemur and tibia ventrodistally with a similar biarticulated seta.

Material examined. CHIBA PREFECTURE. Minami-
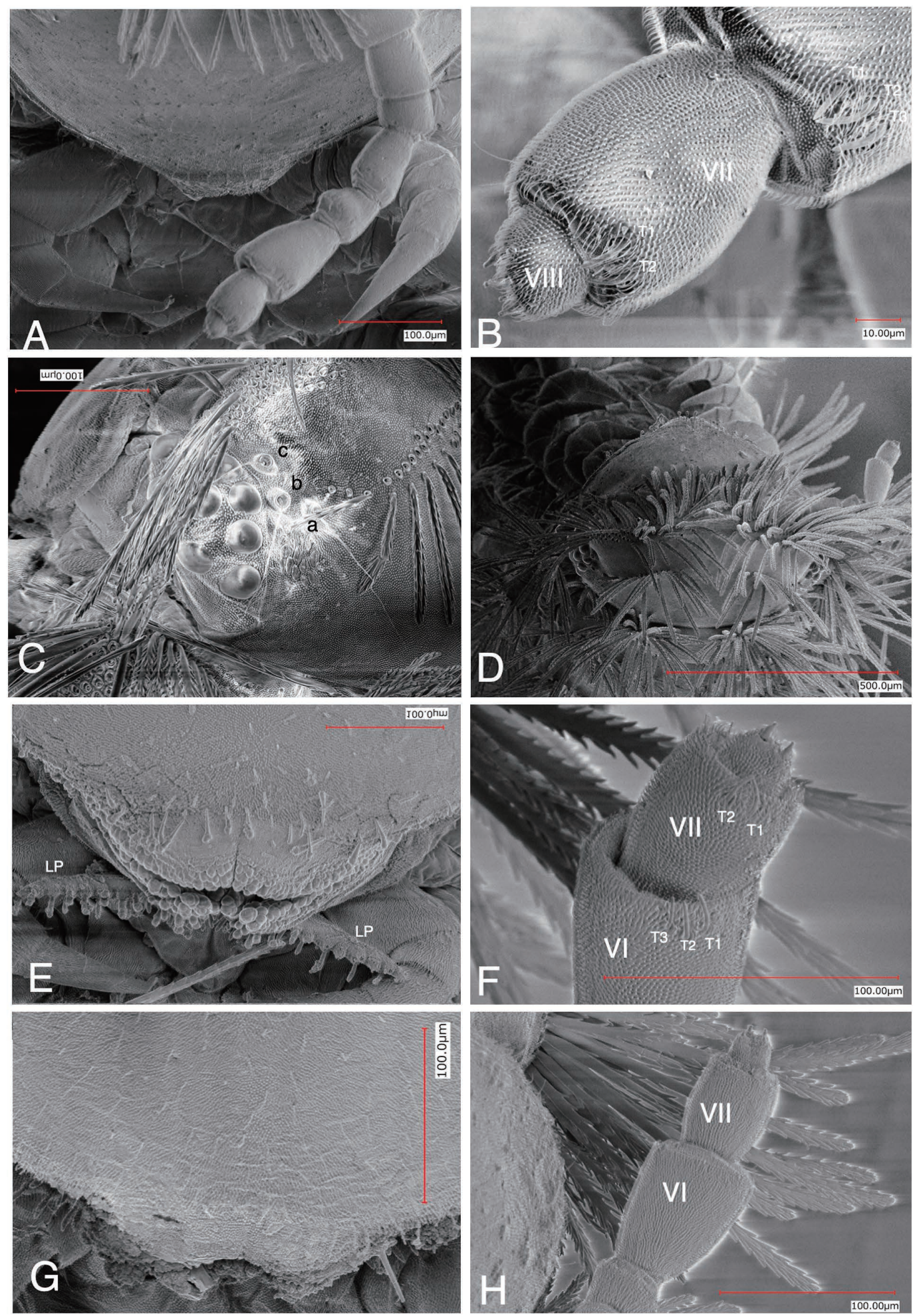

Fig. 6. Scanning electron microscope images of Eugdigraphis spp. A-C: E. takakuwai, male (Suzaki, Seiyo City); A, labrum and left antenna; $B$, ventral view of distal segments of left antenna; $C$, dorsal view of right part of head with 3 trichobothria a, b, c. D-F: E. nigricans, male (Mizushiri Beach, Tottori City); D, head; E, ventral view of labrum with lateral palps (LP) of gnathochilaria; F, Distal segments of left antenna (ventral view). G, H: E. kinutensis, male (Tottori University Campus); G, labrum; H, dorsal view of right antenna and trichomes on head. 
boso City, Chikura-machi, Hedate, Inari Shrine (34.99120833, 139.8250694) (2 juv., 20 June 2019, T. Suzuki); Tateyama City, Fujimi, Okinoshima island (34.99120833, 139.8250694, 10 juv., 20 June 2019, T. Suzuki). —-TOKYO METROPOLIS. Shinjuku Ward, Toyama Park (Hakoneyama) (35.705781, 139.713364), $20 \mathrm{~m}$, under bark of trunks of Zelkova serrata (6 spms., 99\% EtOH, 17 October 2017, SF). —SHIZUOKA PREFECTURE. Kamo-gun, Minami-izu-cho, Irozaki, Hachiman Shrine (34.61388889, 138.85), $40 \mathrm{~m}$ (2 juv., 29 April 2008, NT); Sunto-gun, Shimizu-cho, Tokura, Honjoyama Park (3 spms., $80 \%$, then $99 \% \mathrm{EtOH}$, and 2 spms., $80 \% \mathrm{EtOH}, 2$ January 2018, Y. Obae). —SHIGA PREFECTURE. Nagahama City: Oyori-cho, Iwasakiyama, Norikura Tumulus $(35.431263,136.314631), 150 \mathrm{~m}$, Quercus serrata forest (15 juv., 30 October 2019, NT); Kohoku-cho, Odani-jo Castle (35.455330, 136.276817), $230 \mathrm{~m}$ alt., Deciduous broad-leaved forest (8 juv., 25 October 2018, NT); NishiAzai-cho, Tsukide, Oku-Biwako Parkway (35.499430, 136.160136), $210 \mathrm{~m}$, Cryptomeria japonica forest (1 adult, 20 juv., 30 October 2019, NT). Omi-hachiman City, Aduchi Castle Ruins (35.153276, 136.138340), $90 \mathrm{~m}$ (1 juv., 29 October 2019, NT). - TOTTORI PREFECTURE. Tottori City: Fukube-cho, Sakadani Shrine, 40-70 m, evergreen broad-leaved forest, (1 juv., 99\% EtOH, 18 January 2012, NT); Kokufu-cho, Ube Shrine, 27-32 m (1 adult and 1 juv., 1 June 1999, TM); Mt. Gentayu, $35 \mathrm{~m}$ (2 spms, 21 September 1998, TM); Mt. Gentayu, Ochidani, $40 \mathrm{~m}$, Abies firma and Quercus acuta forest, (1 spm., 99\% $\mathrm{EtOH}$, 18 April 2011, NT); Tottori City Historical Museum, 30 m, Abies firma and Cryptomeria japonica forest (2 spms., 99\% EtOH, 6 December 2011, NT); Mt. Kyusho, 70-220 m, soil litter (7 spms., 14 May 1998; 2 spms., 27 May 1998, TM; 1 spm., 25 June 1998; 5 spms., 24 July 1998; 18 adults and 36 juv., 23 August 1998; 1 juv., 9 October 1998; 1 adult and 9 juv., 2 November 1998; all TM); Ue-machi, Inari Shrine, $30 \mathrm{~m}$ (3 juv., 9 July 1998, TM); Yudokoro-cho, Heiwa-notô Pagoda, 30-110 m, soil litter (5 spms., 28 May 1998; 3 spms., 18 June 1998; 8 spms., 9 July 1998; 3 spms., 1 August 1998; 2 juv., 11 August 1998; 15 adults and 76 juv., 26 August 1998; 2 adults and 1 juv., 10 September 1998; 10 adults and 18 juv., 5 October 1998; 9 juv., 5 November 1998; all TM); Hamasaka, Hamasaka Shrine, 23-40 m, soil litter (1 spm., 4 June 1998; 1 spm., 12 August 1998; 1 juv., 12 August 1998; 1 adult and 2 juv., 14 September 1998; all TM); Koyama, Koyama Shrine, 13-24 m, (1 spm., 8 June 1998. TM; 6 adults and 4 juv., 22 August 1998, TM; 2 spms., 5 December 2011, NT); Koyama, Urayama Hill, Koyama Shrine (35.513090, 134.178836), 20-30 m, soil litter (12 spms., 99\% EtOH, 26 April 2011, NT; 2 adults and 1 juv., 99\% EtOH, 7 January 2018, NT); Koyama, Tenjinyama Hill, 5 m, soil litter (1 spm., 16 August 1998; 6 juv., 5 December 1998; 2 juv., 13 August 1999; 1 male, 23 December 1999: all TM); Fuse, Hie Shrine, 2-20 m (1 male and 1 juv., 26 August 1998; 1 juv., 5 October 1998; 1 juv., 2 June 1999: all TM); Takazumi, Kitano Shrine, $30 \mathrm{~m}$ (1 spm., 5 September 1998, TM). - HIROSHIMA PREFECTURE. Hiroshima City, Mt. Gosaso-zan (34.422470, 132.547088),
$670 \mathrm{~m}$, under barks of Pinus densiflora (12 spms., 11 December 1977, NT). — YAMAGUCHI PREFECTURE. Shimonoseki City: Oogawara Beach, (4 spms., 99\% EtOH, 25 September 2017, Makiko Matsuda); Toyoura-cho, Waita (1 female, 31 August 2017, KK). —-EHIME PREFECTURE. Imabari City, Umashima Shrine, Umashima island (1 spm., 25 November 2000, Haruko Ishikawa); Matsuyama City: Hojo, Kami-Namba, Eryo Shrine, $40 \mathrm{~m}$ (1 spm., 7 February 2010, NT); Takahama, Shiraishi-no-hana Point (3 spms., 23 September 2012, Kazuo Ishikawa); Matsuyama Castle, Soil litter in Castanopsis cuspidata forest, $50 \mathrm{~m}$ (ca. 30 spms., 3 January 1994, NT); Takai-cho, Takai-Hachiman Shrine (1 juv., 24 April 2000, NT). Seiyo City, Mikame-cho, Kyaku (33.388036, 132.429757; 2 females and 3 juv., 24 March 2019, NT); Mikame-cho, Suzaki Coast (33.366568, 132.390543), forest litter of Quercus phillyraeoides forest (3 males, 2 females and 3 juv., 24 March 2019, NT). KOCHI PREF. Tosa-shimizu City, Ashizuri Cape (3 spms., 80\%, then 99\% EtOH, 23 December 2017, Shogo Makita). —OKINAWA PREFECTURE. Nakagusuku-son, Yoshinoura Park $(26.259283,127.792886)$, leaf litter in tree hole of Ficus superba var. japonica (5 spms., 99\% EtOH, 12 March 2018, SK).

Distribution. Honshu (west from Tokyo), Shikoku, Kyushu, the Ryukyu Islands (Okinawa-jima, Kume-jima, Izena-jima and Ishigaki-jima islands: Omine 1965), and Izu Islands (Miyake-jima island: Ishii and Yamaoka 1982).

Minato (1973) reported this species without mentioning subspecies from Otoko-jima island of the Danjo Islands (Nagasaki Prefecture). Likewise, Minato (1969) reported occurrence of Monographis takakuwai s. lat. from Shimokoshiki-jima island and Yamato-hama beach in Amami-Oshima island (Kagoshima Prefecture). Considering the localities are directly facing the ocean, it might be possible that these records are not of E. takakuwai s. str. but of E. nigricans. Thus, these localities are not shown in Fig. 1.

Habitat. This species is usually found from soil litter on the forest floor, though the species can also often be found from crevices under bark of trunks of trees such as Ginkgo biloba (Ginkgoaceae), Pinus densiflora (Pinaceae), Zelkova serrate (Ulmaceae), Aphananthe aspera (Cannabaceae). Takashima and Haga (1950) suggested that this species usually migrates to the trunks of trees from soil litter on the forest floor in winter. On the other hand, Ishii (1977) showed that this species inhabits crevices of tree trunks of Zelkova serrata all year round. The species has been abundantly recorded also from arboreal nests of some species of ants, such as Crematogaster vagula Wheeler, 1928, Tapinoma indicum Forel, 1895, Camponotus nipponicus Wheeler, 1928 (Ishii and Yamaoka 1982, 1983).

Ecology. This species is univoltine and overwinters as adults and juveniles, though both adults and juveniles of various stages can also be seen all year round (see collecting records for several populations made in Tottori City throughout the year). Eggs laid can be seen from July to October according to observations for a population in Ibaraki Prefecture (Ishii 1997). Eggs are $0.4 \mathrm{~mm}$ in long and $0.25 \mathrm{~mm}$ in short diameters (Ishii 1977). The number of eggs 
per batch is ca. 33 on average (Ishii 1997). Each egg batch is covered with body hairs of the female who laid the batch (Murakami 1972). Ishii (1997) reported that the digestive tract was filled with minute fragments of litter.

Remarks. Sierwald and Spelda (2018) placed E. xishuangbanna, described from Yunnan Province in southwestern China, under a junior synonym of E. t. takakuwai citing Nguyen Duy-Jacquemin and Geoffroy (2003) as the source of synonymy. However, no synonymization can be found in the article by Nguyen Duy-Jacquemin and Geoffroy (2003). Thus, E. xishuangbanna should be treated as a different species from E. takakuwai, though we have at present no idea of the relationship between the two species.

This species was first recorded from Japan as Monographis kraepelini Attems, 1907 on the basis of five specimens collected from Shuri (Naha City) of Okinawa-jima island (Takakuwa and Takashima 1942; Takakuwa 1954). Omine (1965) also listed M. kraepelini in the table enumerating distributional records in the Ryukyu Islands (the species is marked on the following islands: Ishigaki-jima, Kume-jima, Ie-jima, and Izena-jima). However, Ishii (1988) concluded that these records are misidentification of E. takakuwai s. str., based on the experience obtained through his extensive surveys in the Ryukyu Islands.

Most of the type specimens of millipedes described by Dr. Yasunori Miyosi had been probably stored in his personal collections (see Takashima 1955). However, one of the author, NT, was not able to find the type specimens of E. t. takakuwai and E. t. nigricans in Dr. Miyosi's collection stored in the warehouse in his home when NT visited his home just after his passing away in 1995.

\section{Eudigraphis nigricans (Miyosi, 1947), stat. rev. [Japanese name: Iso-fusayasude]}

(Figs 1, 4D, 5C, D, 6D-F)

Monographis takakuwai nigricans Miyosi, 1947: 7 (type locality: Enoshima isalnd, Kanagawa Prefecture, Honshu, Japan; type specimens collected by S. Gamo seem to be lost); Takashima and Haga 1950: 23, fig. 2; Takashima and Haga 1952: 18; Miyosi 1959: 58; Miyosi 1965: 741; Miyosi 1979: 478; Ishii 1983: 45; Takano 1973: 4.

Eudigraphis nigricans: Haga 1952: 15; Ishii and Tamura 1995: 233; Ishii 1997: 257; Ishii 1999: 212; Ishii 2002: 289.

Eudigraphis takakuwai nigricans: Ishii 1988: 957, figs 10, 11; Matsumoto and Gamo 1992: 51, fig. 1A-D; Murakami 1993: 97; Nguyen Duy-Jacquemin and Geoffroy 2003: 99; Mimizu Club and Minagoshi 2013: 44, 3 photos; Minagoshi 2017: 50, 3 photos; Kawano 2017: 14, figs 1-12.

Diagnosis. Body 3-4.2 mm long excluding caudal bundle with no difference between sexes. Ground color of body pale yellowish brown in dorsal view, but head black. Body dorsally with a pair of belt-like dark brown markings that run slightly off from both of the rims of each segments of body. Mandible with 8 molar processes and 5 molar combs (for the details in mandible structure; see Ishii 1988). This species can be easily distinguished from E. takakuwai by having a somewhat smaller body with black head. Brown markings are darker and more conspicuous in this species than in E. takakuwai.

Brief description (based on specimens from Mizushiri Coast, Tottori City, Tottori Prefecture). Body length excluding caudal bundle (males): $3.6-4.2 \mathrm{~mm}(n=4$, mean $3.8 \mathrm{~mm})$.

Coloration. Head black. tergites yellowish brown laterally tinted with dark brown.

Head with an anterior row of 20 trichomes per side (Fig. 6D) and a posterior row of 12 trichomes per side (Fig. 6D).

Anntenal article VI with 3 thick basiconic sensilla (T) of equal length; article VII with 2 thick basiconic sensilla (Fig. $6 \mathrm{~F})$. The presence of conical and setiform sensilla were unable to be determined.

Clypeo-labrum with $c a$. 10 scattered setae along posterior margin; anterior margin of labrum granulated (Figs. 6E). Gnathochilarium with slender lateral palp with 12 cylindrical sensilla, medial palp with a group of $c a$. 10 sensilla.

Material examined. TOKYO METROPOLIS. Chiyoda Ward, Hibiya Park, under bark of a tree trunk of Aphananthe aspera (7 spms., 99\% EtOH, 17 October 2017, SF). —TOTTORI PREFECTURE. Tottori City, Mizushiri Beach (35.524599, 134.098788), $3 \mathrm{~m}$ (3 adults and 6 juv., 99\% EtOH, 18 October 2017, NT), same beach (35.525003, 134.099100), $1 \mathrm{~m}$ ( 3 males, 3 females and 12 juv., 27 May 2019, NT). —YYMAGUCHI PREFECTURE. Shimonoseki City: Chofusotoura-cho (6 spms., 99\% EtOH, 25 September 2017, Makiko Matsuda); Toyoura-cho, Inunaki Cape (2 spms., 99\% EtOH, 25 September 2017, Makiko Matsuda); Toyoura-cho, Uka (1 male, 1 September 2017, KK); Tsunoshima island, in the sand of sandy beach (4 spms., 99\% EtOH, 9 May 2018, Makiko Matsuda). _-FUKUOKA PREFECTURE. Kitakyushu City: Moji Ward, Tsunemi (2 spms., 99\% EtOH, 24 September 2017, Makiko Matsuda); Wakamatsu Ward, Hibiki Marine Park (18 spms., 99\% EtOH, 23 June 2017, SK).

Distribution. Honshu, Kyushu, Hachijo-jima island (Takashima and Haga 1952), Nii-jima island (Takano 1973), and Okinawa Islands (Minagoshi 2017; detailed locality unknown, though it was tentatively plotted on Okinawa-jima island in Fig. 1). Most records in Honshu came from southwestern part of Honshu, though the northernmost records extend to Sendai Bay, Miyagi Prefecture for the Pacific coast (Matsumoto and Gamo 1992) and Sado-ga-shima island for the coasts of Sea of Japan (Mimizu Club and Minagoshi 2013).

Habitat. This species is usually found in cracks of rocks on rocky sea cliffs, from shoreline to 1 to $2 \mathrm{~m}$ above from shoreline. Association of this species to rocky seashores is rather strong, though the species can be found sometimes on trunks of trees in the seaside forest (Takashima and Haga 1952). One of us (SF) found a population of E. nigricans under barks of a trunk of tree Aphananthe aspera in Hibiya Park, ca. $1.8 \mathrm{~km}$ away from the nearest shore of the Tokyo Bay.

Ecology. This species is univoltine and overwinters as adults and juveniles. Eggs laid can be seen from June to 
October according to the observation of a population in Amatsu-Kominato, Chiba Prefecture (Ishii 1997). The number of eggs per egg batch varies from 26 on average (Ishii 1997) to ca. 30 (Matsumoto and Gamo 1992). Each egg batch is covered by trichomes of tail brush of the female who laid the batch (Matsumoto and Gamo 1992). Gut content of the species consisted of lichens on the rocks of seashore (Ishii 1997).

Remarks. One of us (KK), found some live individuals floating on the surface of seawater due to surface tension generated by having many long bristles on their bodies off the coast of Uka, Shimonoseki City in Yamaguchi Prefecture (Kawano 2017). This nature seems to facilitate dispersal of the species by raft and current of the sea.

\section{Eudigraphis kinutensis}

(Haga in Takashima and Haga, 1950), stat. rev. [Japanese name: Haiiro-fusayasude]

(Figs 1, 4F, 5E, F, 6G, H)

Monographis takakuwai kinutensis Haga in Takashima and Haga, 1950: 24, fig. 3 [male holotype (NSMT-My 140) from Kinuta (=Okura-cho), Setagaya Ward, Tokyo Prefecture, Japan, 17 October 1949, S. Haga leg.; 6 males and 7 females (MSMT-My 141) from the same locality, 17 October 1949]; Miyosi 1959: 58; Miyosi 1965: 741; Miyosi 1979: 478.

Eudigraphis kinutensis: Haga 1952: 15; Ishii and Tamura 1995: 233; Ishii 1999: 212; Ishii 2002: 289.

Eudigraphis takakuwai kinutensis: Ishii 1988: 958, figs 12, 13; Murakami 1993: 97; Nguyen Duy-Jacquemin and Geoffroy 2003: 99; Ishii 2005: 820, 1 photo; Mimizu Club and Minagoshi 2013: 45, 2 photos; Minagoshi 2017: 50, 2 photos; Ishii 2018: 864,1 photo.

Diagnosis. Body 2.5-3 mm long excluding caudal bundle with no difference between sexes. Body gray when alive. Mandible with 8 molar processes and 6 molar combs (for the details of diagnosis in mandible structure; see Ishii 1988). This species, when it is alive, can be easily distinguished from E. takakuwai and E. nigricans by its small and gray body (Figs 4, 5).

Brief description (based on specimens from Tottori University Campus, Tottori City, Tottori Prefecture). Body length (males) 2.6-3.0 mm $(n=4$, mean $2.7 \mathrm{~mm})$. Caudal bundle $0.48-0.50(n=2$, mean 0.49$)$.

Coloration. Head and tergites grey when photographed in the wild (Fig. 4F). Caudal bundle white (Figs 4F, 5E).

Head with an anterior row of $c a .20$ trichomes per side and a posterior row of $c a .8$ trichomes per side.

The antennae with 8 articles and 4 sensitive cones at the tip. Article VI with 3 thick basiconic sensilla (T) of equal length; article VII with 2 thick basiconic sensilla (Fig. $6 \mathrm{H}$ ).

Clypeo-labrum with 7 scattered setae along posterior margin; anterior margin of labrum smooth, concaved at the middle part (Fig. 6G). Gnathochilarium with slender lateral palp with 7 cylindrical sensilla.

Specimens examined. TOKYO METROPOLIS. Shibuya
Ward, Yoyogi Park (near Yoyogi Park Service Center), Yoyogi-Jinnan-cho (35.672032, 139.692492), $34 \mathrm{~m}$, under bark of a tree trunk of Zelkova serrata, (1 spm, 99\% EtOH, 6 November 2017, SF). Suginami Ward, Omiya 2 chome, Wadabori Park (south of the First Athletic Field; 35.683649, 139.641538), $37 \mathrm{~m}$, under bark of trunks of Zelkova serrata, (9 spms., 99\% EtOH, 6 November 2017, SF). Nerima Ward: Hikarigaoka 4 chome, Hikarigaoka Park (west of Konchu Harappa; 35.763741, 139.62673638), under bark of trunks of Zelkova serrata (3 spms., 99\% EtOH, 6 November 2017, SF); Shakujii-dai 1-26, Shakujii Park (35.737581, 139.598046), $40 \mathrm{~m}$, under bark of trunks of Zelkova serrata, (8 spms., 99\% EtOH, 17 October 2017, SF). — HYOGO PREFECTURE. Sanda City, Yayoigaoka, Fukada Park $(34.88625,135.1999444), 190 \mathrm{~m}$, on trunks of Zelkova serrata (ca. 30 spms., 25 September 2013, Takeshi Suzuki; 20 spms., 27 September 2013, Takeshi Suzuki). — TOTTORI PREFECTURE. Tottori City: Ochidani Park, Bairi-an (35.499236, 134.243166), $10 \mathrm{~m}$, under bark of trunks of Zelkova serrata, (30 spms., 99\% EtOH, 10 November 2017, NT; 10 males, 22 females and 148 juv., 10 November 2017, NT); Koyama-cho Minami, Campus of Tottori University (in front of Fac. Engineering; 35.515699, 134.172517), $16 \mathrm{~m}$, under bark of trunks of Zelkova serrata, (2 males, 4 females and 19 juv., 99\% EtOH, 13 November 2017, NT; 8 males, 10 females and 71 juv., 5 January 2019, NT); Koyama-cho Minami, Campus of Tottori University (backyard of the University Library; 35.515328, 134.172726), $16 \mathrm{~m}$, under bark of trunks of Zelkova serrata (8 juv., 99\% EtOH, 13 November 2017, NT); Koyama-cho-Minami, Tenjinyama Hill $(35.509638,134.176514), 20 \mathrm{~m}$, under bark of trunks of Zelkova serrata (20 spms., 7 January 2018, NT). - EHIME PREFECTURE. Matsuyama City, Ishite-gawa Park, Nagaki-machi (33.835279, 132.775741), 32 m, under bark of a tree trunk of Platanus $\times$ acerifolia (25 adults and 15 juv., 99\% EtOH, 1 January 2018, NT). —YAMAGUCHI PREFECTURE. Shimonoseki City, Ozuki Elementary School, Ozuki-cho, (3 adults and 4 juv., 99\% EtOH, 7 January 2018, KK).

Distribution. Honshu (southwestern part, Tochigi Prefecture and southward), and Shikoku (Fig. 1).

Habitat. Under exfoliating bark of the trunks of deciduous broad-leaved trees, such as Zelkova serrata, Ulmus parvifolia (Ulumaceae), and Platanus spp. (Platanaceae).

Ecology. This species is univoltine and overwinters as adults and juveniles of various stages. Egg batches can be seen from June to October according to an observation of a population in Ichihara City, Chiba Prefecture (Ishii 1997). Number of eggs per egg batch was 31.7 on average (Ishii 1997). Ishii (1997) reported that this species feeds upon the inner surface of exfoliated barks and lichens from the trunks of trees.

Remarks. Three different names have been used as Japanese name of this species: "Haiiro-chibi-ke-fusayasude", "Haiiro-chibi-fusayasude", "Haiiro-fusayasude". Takashima and Haga (1950) used "Haiiro-chibi-ke-fusayasude" as Japanese name of the species ("subspecies" at that time) in their original description of the form. Miyosi (1959) dropped 
"ke", that means "hair" in Japanese, from the name and used "Haiiro-chibi-fusayasude", without stating any reason for the change (thus it is possible that this was just a typographical error). Murakami (1993) further dropped "chibi" from the name and used "Haiiro-fusayasude". We suspect that this change was made for his solicitude on the fact that "chibi", which means "small" or "little" in Japanese, had been often considered a kind of discriminatory word in the Japanese society. We adopt "Haiiro-fusayasude", which represents "gray" + "tufted millipede" in Japanese, here, because (1) this name represents the diagnostic features of the species sufficiently, and (2) use of "chibi" in the names of animals remains controversial in Japan and we consider that we should avoid use of such words when possible to avoid insult or offense.

This species looks gray when perched on trunks of trees. However, specimens of the species dipped in ethanol do not look gray but have a light yellow-brown body laterally tinted with brown; hence preserved specimens are not easily discernible from E. takakuwai. This species also looks brown in photos when specimens were photographed with a flashlight against white background, or even in the stroboscopically illuminated photos taken in the field (e.g., Minagoshi 2017: 50 ). Thus, coloration of the body seems to change depending on incidence of lighting.

\section{Acknowledgments}

We thank Dr. Kiyoshi Ishii (Showa University) and Yasunori Hagino (Chiba Prefectural Museum) for their help in obtaining some of the literature and valuable information and to Dr. Mercedes Burns (University of Maryland, Baltimore County) for her help in English improvements to the manuscript. Thanks are also due to Yuito Obae (Tottori University of Environmental Studies) and Makiko Matsuda for offering valuable specimens for DNA analysis. Dr. Takeshi Suzuki (Museum of Nature and Human Activities, Hyogo) allowed us to use his personal records of E. kinutensis from Sanda City and offered live specimens of E. takakuwai from Ciba Prefecture. We thank Takashi Muramatsu (Tottori University) for his kind help for using Keyence SEM and Dr. Ken-ichi Okumura (National Museum of Nature and Science, Tokyo) for his help in getting the data of the type specimens of Eudigraphis kinutensis. Thanks are also due to following people who sent us Eudigraphis specimens at our disposal: Shogo Makita, Kazuo Ishikawa, Haruko Ishikawa, Takashi Mekata. This study was supported in part by a KAKENHI grant (JP17K07534) to NT from the Japan Society for Promotion of Science (JSPS). We also thank two anonymous referees for their kind and invaluable suggestions that improved our final draft very much.

\section{References}

Capella-Gutiérrez, S., Silla-Martínez, J. M., and Gabaldón, T. 2009. tri$\mathrm{mAl}$ : a tool for automated alignment trimming in large-scale phy- logenetic analyses. Bioinformatics 25: 1972-1973.

Eisner, T., Eisner, M., and Deyrup, M. 1996. Millipede defense: Use of detachable bristles to entangle ants. Proceedings of the National Academy of Sciences of the United States of America 93: 1084810851.

Gröning, J. and Hochkirich, A. 2008. Reproductive interference between animal species. Quarterly Review of Biology 83: 257-282.

Haga, A. 1951. Diplopoda of Tokyo. Acta Arachnologica 12: 101. [In Japanese]

Haga, S. 1952. Polyxenid millipedes resembling larva of dermestid beetles. Otoshibumi (Reports of the Insect Study Circle of the Tokyo University of Agriculture) 11: 14-17. [In Japanese]

Hopkin, S. P. and Read, H. J. 1992. The Biology of Millipedes. Oxford Science Publications, Oxford, 233 pp.

Huynh, C. and Veenstra, A. A. 2018a. Two new species of penicillate millipedes (Diplopoda, Polyxenidae) from Phu Quoc Island in southern Vietnam. Zootaxa 4402: 283-302.

Huynh, C. and Veenstra, A. A. 2018b. Two new Lophoturus species (Diplopoda, Polyxenida, Lophoproctidae) from Queensland, Australia. ZooKeys 741: 133-154.

Ichisawa, K., Hayashi, M., and Tsurusaki, N. 2012. Arachnida, Myriapoda, and land Isopoda of Kamogaiso Beach in Tottori Prefecture. Natural History Research of San'in 7: 9-14. [In Japanese]

Ishii, K. 1977. Life history of Monographis takakuwai takakuwai Miyosi. Kiyosumi 6: 35-39. [In Japanese]

Ishii, K. 1983. Myriapods of Izu Peninsula, First report. Kiyosumi 10: 43-48. [In Japanese]

Ishii, K. 1988. On the significance of the mandible as a diagnostic character in the taxonomy of penicillate diplopods (Diplopoda: Polyxenidae). The Canadian Entomologist 120: 955-963.

Ishii, K. 1997. Comparative biological study of the penicillate diplopods in Japan (Diplopoda, Penicillata). Pp. 257-262. In: Enghoff, H. (Ed.) Many-Legged Animals-A Collection of Papers on Myriapoda and Onychophora. Proceedings of the Tenth International Congress of Myriapodology, Copenhagen, 29 July-2 August, 1996. Entomologica Scandinavica Supplement No. 51. Scandinavian Entomology, Lund.

Ishii, K. 1999. A list of myriapod species in Chiba Prefecture with general remarks on the fauna. Pp. 206-218. In: Chiba Zoological Society (Ed.) Natural History of Animals in Chiba Prefecture, Japan. Bun-ichi Sogo Publishing, Tokyo. [In Japanese]

Ishii, K. 2000. The myriapods from the Imperial Palace Tokyo, Japan. Memoirs of the National Science Museum of Nature and Science, Tokyo 35: 103-114. [In Japanese]

Ishii, K. 2002. Diplopoda. Pp. 287-296. In: Research Foundation of History of Chiba Prefecture (Ed.) Natural History of Chiba Prefecture. Vol. 6. Animals of Chiba Prefecture 1. Land and Fresh Water Animals. Chiba Prefecture, Chiba. [In Japanese]

Ishii, K. 2005. Eudigraphis takakuwai kinutensis. P. 820. In: Division of Natural Environment, Department of Forest Management of Tochigi Prefecture and Tochigi Prefectural Museum (Eds) Red Data Book Tochigi. Tochigi Prefecture, Utsunomiya. [In Japanese]

Ishii, K. 2018. Eudigraphis takakuwai kinutensis. P. 864. In: Division of Natural Environment, Department of Environment and Forest of Tochigi Prefecture and Tochigi Prefectural Museum (Eds) Red Data Book Tochigi 2018. Tochigi Prefecture, Utsunomiya. [In Japanese]

Ishii, K. and Tamura, H. 1995. The mandibular structure as a diagnostic character in taxonomy of diplopods. Acta Zoologica Fennica 196: 232-235.

Ishii, K. and Yamaoka, H. 1982. The species and number of symbiotic penicillate millipedes in arboreal ant nests. The Canadian Entomologist 114: 767-768.

Ishii, K. and Yamaoka, H. 1983. An example of a milliped species 
Monographis takakuwai that cohabits with ants in their arboreal nests in Mt. Kiyosumi. Kiyosumi 10: 11. [In Japanese]

Katoh K. and Standley D.M. 2013. MAFFT multiple sequence alignment software version 7: improvements in performance and usability. Molecular Biology and Evolution 30: 772-780.

Kawano, K. 2017. Millipeds of Shimonoseki City. The Firefly Museum of Toyota Town, Shimonoseki, $30 \mathrm{pp}$. [In Japanese]

Kumar S., Stecher G., and Tamura K. 2016. MEGA7: Molecular Evolutionary Genetics Analysis Version 7.0 for Bigger Datasets. Molecular Biology and Evolution 33: 1870-1874.

Kuwahara, Y. 1993. Myriapoda from coastal areas of the Kii Peninsula. Takakuwaia 25: 12-18. [In Japanese]

Matsumoto, T. and Gamo, S. 1992. Notes on two penicillate diplopods, Eudigraphis takakuwai nigricans (Miyosi) and E. takakuwai takakuwai (Miyosi) found on the coast of Sagami Bay (Diplopoda, Penicillate, Polyxenidae). Bulletin of Scientific Education Center of Faculty of Education, Yokohama National University 8: 51-62. [In Japanese]

Mayr, E. and Ashlock, P. D. 1991. Principles of Systematic Zoology, Second Edition McGraw-Hill, Inc., New York, 475 pp.

Mimizu Club and Minagoshi, Y. 2013. Field Guide to Small Animals under Fallen Leaves. Gijutsu-Hyoron-sha Publishing, Tokyo, 127 pp. [In Japanese]

Minagoshi, Y. 2017. Handbook of Little Animals under Fallen Leaves. Bun-ichi Sogo Shuppan Publishing, Tokyo, 120 pp. [In Japanese]

Minato, H. 1968. Diplopoda of the southern part of the Kii Peninsula. Nankiseibutu 10: 19-25. [In Japanese]

Minato, H. 1969. Distributional data of Diplopoda from Japanese Islands (I). Atypus 51/52: 33-35. [In Japanese]

Minato, H. 1971. Diplopoda of the southern part of the Kii Peninsula (III). Nankiseibutu 13: 45-47. [In Japanese]

Minato, H. 1973. Myriapoda of the Danjo Islands. Pp. 127-128. In: Biological Society of Nagasaki Prefecture (Ed.) Fauna and Flora of the Danjo Islands. Biological Society of Nagasaki Prefecture, Nagasaki. [In Japanese]

Miyosi, Y. 1947. Eine neue Art von Monographis aus Japan. Acta Arachnologica 10: 1-8. [In Japanese]

Miyosi, Y. 1959. Über Japanische Diplopoden. Arachnological Society of East Asia, Osaka, 223 pp., 19 pls. [In Japanese]

Miyosi, Y. 1965. Diplopoda. Pp. 739-748. In: Okada, Y., Uchida, S., and Uchida, T. (Eds) New Illustrated Encyclopedia of the Fauna of Japan, Vol. 2. Hokuryu-kan Publishing, Tokyo.

Miyosi, Y. 1979. Diplopoda. Pp. 478-480. In: Uchida, T. (Ed.) Illustrated Encyclopedia of the Fauna of Japan, Newly compiled. Hokuryu-kan Publishing, Tokyo. [In Japanese]

Murakami, Y. 1972. Myriapoda of Ehime Prefecture. Pp. 83-88. In: Science Division of Research Group of High School Education in Ehime Prefecture (Ed.) Living Organisms of Ehime. Research Group of High School Education in Ehime Prefecture, Matsuyama. [In Japanese]

Murakami, Y. 1993. Arthropoda: Diplopoda, Pauropoda, Chilopoda, Symphyla. Pp. 95-106. In: Nature Conservation Bureau (Wildlife Division) of the Environment Agency, Japan (Ed.) Checklist of Species of Wild Animals and Plants in Japan (Invertebrate III). Japan Wildlife Research Center, Tokyo. [In Japanese]

Nguyen Duy-Jacquemin, M. and Condé, B. 1967. Morphologie et Géonémie du genre Monographis Attems. Mitteilungen aus dem Hamburgischen Zoologischen Museum und Institut 64: 43-81.

Nguyen Duy-Jacquemin, M. and Geoffroy, J.-J. 2003. A revised comprehensive checklist, relational database, and taxonomic system of reference for the bristly millipedes of the world (Diplopoda, Polyxenida). African Invertebrates 44: 89-101.

Ogata, K. 1997. Diplopoda of Aichi. Bulletin of the Horaijisan Natural Science Museum 26: 1-22. [In Japanese]
Omine, T. 1965. On the millipedes of Okinawa and their distribution. The Journal of Okinawa University 6: 1-15. [In Japanese]

Rambaut, A., Suchard, M. A., Xie, D., and Drummond A. J. 2014. Tracer v1.6. Available at http://beast.bio.ed.ac.uk/Tracer (17 July 2014)

Shinohara, K. and Ishii, K. 1984. Review of scientific names of Japanese myriapods. VI. Generic name of Japanese Penicillata. Takakuwaia 16: 1-2. [In Japanese]

Shinohara, K. and Tanabe, T. 1999. Diplopoda. Pp. 647-683. In: Aoki, J. (Ed.) Pictorial Keys to Soil Animals of Japan. Tokai University Press, Tokyo. [In Japanese]

Shinohara, K., Tanabe, T., and Korsos, Z. 2015. Myriapoda: Diplopoda. Pp. 943-984. In: Aoki, J. (Ed.) Pictorial Keys to Soil Animals of Japan, 2nd edition. Tokai University Press, Hadano. [In Japanese]

Short, M., and Huynh, C. 2013. Four new species of Unixenus Jones. 1944 (Diplopoda, Penicillata, Polyzenida) from Australia. ZooKeys 278: 75-90.

Short, M., and Vahtera, V. 2017. Phylogenetic relationships of millipedes in the subclass Penicillata (Diplopoda) with a key to the genera. Journal of Natural History 51: 2443-2461.

Sierwald, P. and Spelda, J. 2018. MilliBase. Eudigraphis xishuangbanna Ishii \& Yin, 2000. Available at http://www.millibase.org/aphia. php? $=$ taxdetails\&id $=1032959$ (15 November 2019)

Sierwald, P. and Spelda, J. 2019. MilliBase. Eudigraphis takakuwai (Miyosi, 1947). Available at http://www.millibase.org/aphia.php?p= taxdetails\&id $=1030929$ (15 November 2019)

Silvestri, F. 1948. Tavola sinottica dei generi dei Diplopoda Penicillata. Bollettino del R. Laboratorio di entomologia agraria di Portici 8: 214-220.

Stamatakis, A. 2014. RAxML version 8: a tool for phylogenetic analysis and post-analysis of large phylogenies. Bioinformatics 30: 13121313.

Takakuwa, Y. 1954. Japanese Diplopoda. Japan Society for the Promotion of Science, Tokyo, $241+10$ pp. [In Japanese]

Takakuwa, Y. and Takashima, H. 1942. Overview of Myriapoda of Micronesia with notes on the discovery of Polyxenidae in Japan. Acta Arachnologica 7: 120-124. [In Japanese]

Takano, M. 1973. Diplopoda and Chilopoda of Nii-jima Island, Japan. Takakuwaia 6: 3-4. [In Japanese with English summary]

Takano, M. 2001. Myriapods of the Institute for Nature Study in Tokyo. Report of the Institute for Nature Study in Tokyo 33: 219-227. [In Japanese]

Takashima, H. 1955. [List of the myriapod type specimens existing in Japan (II)]. Circular of the Japanese Society of Systematic Zoology 9: 5-8. [In Japanese]

Takashima, H. and Haga, A. 1950. Notes on Polyxenidae of Japan. Acta Arachnologica 11: 21-26. [In Japanese]

Takashima, H. and Haga, A. 1952. On the diplopods collected in the Seven Islands of Izu, Japan. Acta Arachnologica 13: 17-26. [In Japanese]

Tanabe, A. S. 2011. Kakusan4 and Aminosan: two programs for comparing nonpartitioned, proportional and separate models for combined molecular phylogenetic analyses of multilocus sequence data. Molecular Ecology Resources 11: 914-921.

Tanabe, T. 1992. Diplopoda of Is. Kumejima. Takakuwaia 24: 65-66. [In Japanese]

Tanabe, T. and Sota, T. 2008. Complex copulatory behavior and the proximate effect of genital and body size differences on mechanical reproductive isolation in the millipede genus Parafontaria. The American Naturalist 171: 692-699.

Tsurusaki, N. 1999. Soil arthropod diversity on fragmented woodlands in the Tottori Plains, Honshu, Japan, and its conservation. Journal of the Faculty of Education and Regional Sciences, Tottori University 1: 57-68. [In Japanese]

Tsurusaki, N. 2002. Check-list of millipedes of Matsuyama City (Ehime 
Prefecrue, Shikoku, Japan). Pp. 151-152. In: Matsuyama Wildlife Research Council (Ed.) Check-list of the Wild Animals and Plants of Matsuyama City, 2002. Matsuyama City, Matsuyama. [In Japanese]

Tsurusaki, N. 2012. A list of millipedes (Diplopoda) of Matsuyama City, Ehime Prefecture, Shikoku, Japan. 2nd version. Pp. 285-286. In: Ishikawa, K. (Ed.) Checklist of the Wild Animals, Fungi, and Plants of Matsuyama City, 2012. The Department of Environment of Matsuyama City, Matsuyama. [In Japanese]

Wade, C. M. and Mordan, P. B. 2000. Evolution within the gastropod molluscs; using the ribosomal RNA gene-cluster as an indicator of phylogenetic relationships. Journal of Molluscan Studies 66: 565-570.

Wesener, T. and Conrad C. 2016. Local hotspots of endemism or artifacts of incorrect taxonomy? The status of microendemic pill millipede species of the genus Glomeris in northern Italy (Diplopoda, Glomerida). PLoS ONE 11: e0162284.

Winston, J. E. 1999. Describing Species. Columbia University Press, New York, $518 \mathrm{pp}$. 